Old Dominion University ODU Digital Commons

History Faculty Publications

History

1998

\title{
Trifling With Holy Time: Women and the Formation of the Calvinist Church of Worcester, Massachusetts, 1815-1820
}

Carolyn J. Lawes

Old Dominion University, clawes@odu.edu

Follow this and additional works at: https://digitalcommons.odu.edu/history_fac_pubs

Part of the History of Religion Commons, and the United States History Commons

\section{Repository Citation}

Lawes, Carolyn J., "Trifling With Holy Time: Women and the Formation of the Calvinist Church of Worcester, Massachusetts, 1815-1820" (1998). History Faculty Publications. 26.

https://digitalcommons.odu.edu/history_fac_pubs/26

\section{Original Publication Citation}

Lawes, C. J. (1998). Trifling with holy time: Women and the formation of the Calvinist Church of Worcester, Massachusetts, 1815-1820. Religion \& American Culture, 8(1), 117-144. doi:10.2307/1123916

This Article is brought to you for free and open access by the History at ODU Digital Commons. It has been accepted for inclusion in History Faculty Publications by an authorized administrator of ODU Digital Commons. For more information, please contact digitalcommons@odu.edu. 


\section{Trifling with Holy Time: Women and the Formation of the Calvinist Church of Worcester, Massachusetts, 1815-1820}

\section{Carolyn J. Lawes}

It was half past nine on a quiet Monday night in April 1818. Elizabeth Tuckerman Salisbury, known throughout Worcester as "Madame Salisbury" in deference to her family's wealth and social position, was passing a serene evening at home with her niece and adopted daughter, Eliza Weir. Her husband, Stephen, a merchant and the town's wealthiest citizen, was away on business. The Salisbury mansion's comfortable drawing room was pleasant, graced by Elizabeth's harp and a piano bought expressly for Eliza. ${ }^{1}$

Suddenly, the peace was shattered as something crashed violently against the front window. Salisbury immediately "call'd in the people" (the servants) for protection. Venturing outside, they spotted no one lurking about but did find two good-sized stones, one weighing over half a pound. Peering out into the now still night, Elizabeth Salisbury noted that "it was very dark, \& no one appeared to be in the street. [Y]ou may suppose I did not recover my tranquil[1]ity very soon." ${ }^{2}$

The next morning, Salisbury summoned her nephew by marriage, Daniel Waldo, a merchant and the town's second-wealthiest citizen. Waldo hurried to her side with disturbing news of his own: "he had his trees broken that night, \& the one preceeding [sic], he supposed by the same person or persons" who had thrown the rocks. Musing over the broken trees and shattered glass, Waldo suspected a political motive behind the attacks, which had occurred on the evening of an election that decided whether he retained his seat in the state senate. Waldo explained that "there had been great exertions made by some disaffected person," costing him not just a few trees but also one hundred votes as well. If, indeed, the vandalism had been linked to the election, it would cease now that the votes had been cast. Heartened by Waldo's conjecture, Salisbury wrote confidently to her husband that there was no cause for alarm, since "there is not the least probability of [the attack] being repeated." A reward of one hundred dollars 
for information about the "evil-minded" vandals yielded no suspects, and the night visitors were never identified. ${ }^{3}$

Yet, if the destruction of Waldo's property were indeed an act of his political opposition, then why the attack on the Salisbury home? None of the Salisburys was active in politics, nor could the women vote. But the senate election was not the only source of intense conflict in Worcester. For, in the spring of 1818, Daniel Waldo's unmarried sisters, Rebecca Waldo and Sarah Waldo, and their aunt Elizabeth Salisbury were embroiled in a feud that threatened to tear apart the community's oldest institution, the First (Congregational) Church. From 1815 through 1820, the three women defied gender conventions by challenging the authority of their minister. Rather than "trifle with holy time," as Elizabeth Salisbury expressed it, they withdrew from the First Church to found the (Congregational) Calvinist Church, sparking an acrimonious debate over the nature of authority within the church. ${ }^{4}$

The history of the Worcester schism occurs at the intersection of scholarly debates over the feminization and democratization of American religion. The feminization of New England Protestantism is an argument of such clarity and apparent empirical support that it has become virtually axiomatic among scholars, who argue that, in the era of the Second Great Awakening, religious women were so numerous and so active that they succeeded in feminizing the churches. ${ }^{5}$ At the same time, historians of religion have characterized the early nineteenth century as a period of church democratization as new denominations successfully challenged the hegemony of the standing order. ${ }^{6}$ Recently, however, historians of women have pointed to the limited nature of feminization and the gendered character of democratization. A study of orthodox Congregational missionary women argues that scholars have overemphasized the pervasiveness of the Second Great Awakening's Arminian theology and suggests that, in the case of orthodox Calvinists, the theological shifts were "less empowering for women [than] has generally been represented. ${ }^{\prime 7}$ Other work asserts that it was primarily within marginal or dissenting religions, such as Shakerism, that women exercised institutional power. A study of Baptist churches in New England, however, finds that moving from the margin to the mainstream meant embracing patriarchalism and hierarchical relations, stripping Baptist women of the relative equality they had once enjoyed. Women's spiritual equality, this historian notes, was a weak foundation for women's social equality. ${ }^{8}$ Taken together, these new studies argue that the feminization of American Protestantism in the early nineteenth century was more nu- 
merical than substantial and that the benefits of the democratization of churches were largely reserved for men. ${ }^{9}$

The events in Worcester illustrate the ways the forces of feminization and democratization could come together to promote women's religious autonomy in a mainstream, orthodox Congregational church. In contrast to dissenting denominations, the First Church of Worcester confronted disestablishment from the other side of the fence; it was the established church, now forced to make the case for a peculiar claim upon its members. Orthodox Congregational women were thus faced with novel opportunities to assert themselves. This article argues that the feminization of religion involved more than numbers and more than sentiment. Rather, the disestablishment of Congregationalism fractured the church's traditional institutional power, creating new social and economic relations in the churches and making it possible for some women to act upon their acknowledged spiritual autonomy. The fracturing of power in the churches, in addition to women's continuing numerical dominance, promoted the feminization of religion.

This process can be seen at work in the Calvinist Church of Worcester, Massachusetts. The self-described "heart of the commonwealth," neither frontier nor urban, Worcester encountered the stresses common to many towns in New England as it developed and diversified in the early nineteenth century. As a county seat, Worcester was a meeting ground for merchants, lawyers, and politicians; moreover, it was situated at the crossroads of numerous stage lines joining metropolitan Boston to the expanding West. Worcester's leading citizens were keenly aware of their town's potential for growth and wasted little time fostering the development of banks and transportation networks in the peace following the War of 1812. It was in this atmosphere of optimistic expectation that dissent began to grow in the community's oldest church. ${ }^{10}$

The Calvinist Church of Worcester had its origins in the frustrations of three women who, because they were excluded from participating in the selection of a new minister, refused to accept his authority. As Anne Hutchinson had two centuries before, these women laid claim to religious autonomy and self-determination and exercised the power implicit in their spiritual equality to command and to criticize the male church leadership. Unlike Anne Hutchinson, however, they were able to do so while remaining within the fellowship of Congregational churches. The Worcester dissidents were assisted in their revolt by their unusual wealth, which, in the era of disestablishment, gave them considerable power within the church. By 1820, the dissidents and their male allies had founded the orthodox Congrega- 
tional Calvinist Church, which instituted universal adulthood suffrage in the election of ministers. In the case of Worcester's Calvinist Church, the feminization and democratization of Protestantism bore fruit as the established church became only one among many.

In 1815, the minister of the First Church of Worcester, the Reverend Samuel Austin, announced his intention to assume the presidency of the University of Vermont. As was true for many congregations at this time, the harmony of the First Church dissipated in the course of settling upon a successor. ${ }^{11}$ At the eye of the maelstrom were Rebecca Waldo, Sarah Waldo, and their aunt by marriage, Elizabeth Salisbury. ${ }^{12}$ The Waldos and Salisbury were unusual women in that each controlled a sizable fortune in her own right. The unmarried Waldo sisters had inherited large sums of money, and, by 1827, each was assessed at more than $\$ 35,000$. Elizabeth Salisbury was even wealthier; in 1846, her estate was appraised at more than $\$ 125,000 .^{13}$ Their fortunes not only landed Rebecca Waldo, Sarah Waldo, and Elizabeth Salisbury at the very top of local tax lists, far ahead of almost all the men in Worcester, but also among the nation's elite. ${ }^{14}$ Barred by their sex from holding formal positions of leadership and power in the community, these economically independent women asserted themselves in the town church. They thus did not hesitate to speak out when the Reverend Austin's replacement, Charles A. Goodrich, proved disappointing.

Through no fault of his own, Goodrich's ministry in the First Church began under a cloud. Samuel Austin was a preacher of firm and outspoken beliefs, a New Divinity Calvinist who once resigned a post because the congregation refused to repudiate the Halfway Covenant. He had prepared for the ministry under Jonathan Edwards, Jr., collected and published some of the works of Jonathan Edwards, Sr., and was married to Jerusha Hopkins, daughter of renowned conservative theologian Samuel Hopkins. In his commanding appearance and "fearless spirit and firmness," Austin reminded his parishioners, for good or for ill, of the Puritan martyrs of old. A minister of local and national prominence, much in demand as a speaker, Austin had set a precedent of forceful and austere spirituality that might have proved difficult for anyone to equal. ${ }^{15}$

The task facing his successor was all the more trying because Austin did not officially vacate the First Church's pulpit. The growing heterodoxy of Protestantism had prompted calls from dissenting sects for the disestablishment of Congregationalism and raised the question of who owned the ministerial lands that had long since been set aside for support of the town's church. In 1815, the First Church was in the midst of protracted litigation with the Second (Unitarian) 
Church over control of Worcester's ministerial lands. As joint plaintiffs in the lawsuit, Austin and the First Church considered it improvident to sever their official connection until the case was resolved. Thus, although settled in Vermont, Austin remained the official pastor of the First Church, a technicality that would spawn numerous complications. When the Reverend Charles A. Goodrich rode into town in autumn 1816, it was as junior pastor to an absent and, to some, greatly missed patriarch. ${ }^{16}$

Signs that Goodrich's tenure would be contentious first arose during the year-long search to fill the pulpit. ${ }^{17}$ According to the church's version of events, the Waldo family proved "unusually solicitous" about Austin's replacement, forcing the congregation to pay "a scrupulous regard to the views, feelings and advice of this family." 18 The Waldos could command such deference because of their critical financial support. Although the formal disestablishment of Congregationalism would not arrive until 1833, Massachusetts passed the Religious Freedom Act in 1811, which required towns to apportion the local church tax among its various denominations according to the size of each church's membership. Some towns, such as Worcester, ceased collecting the tax altogether, compelling churches to raise money on their own by levying a tax on the property of communicants who were heads of households. ${ }^{19}$ The Waldos were by far the wealthiest taxpayers in the First Church, and their financial contributions were considerable (as a married woman whose husband did not belong to the First Church, Elizabeth Salisbury was not subject to its tax). In 1816, the year the schism began, the Waldo family alone supplied slightly more than one-quarter of the First Church's tax revenues. Their money bought them influence, prompting bitter complaints about those whose "claims to consideration over most others are founded entirely on property." ${ }^{20}$

The new minister of the First Church thus had good reason to court the endorsement of the Waldos. Goodrich boasted that he had been selected with their blessing because they had had "a presentiment ... that he would come up to their prescribed standard of excellence." In fact, Goodrich insisted, the family was so pleased that they offered "to furnish the pulpit with a curtain and cushion." ${ }^{21}$ It was thus all the more shocking when Daniel Waldo, on behalf of his sisters and Salisbury-who, as women, were not entitled to vote-cast his ballot against Goodrich. But the church decided "it was now time to act with decision and independence" and soundly outvoted Waldo sixty-four to two. The Waldos and Salisbury found themselves increasingly isolated within the church that, under Austin, had shown deference to and respect for their social and economic standing. ${ }^{22}$ 
The election of Goodrich over the objections of the Waldos and Salisbury sparked a four-year battle for control of the First Church. The dissidents' aversion to Goodrich formally focused upon their suspicion that he was insufficiently orthodox, a potentially serious allegation. Yet, they could name no specific breach of Congregational doctrine. When pressed, they offered only vague examples. At tea one day, the Waldos declared, Goodrich had disparaged John Calvin and derided "those who wanted the cords of orthodoxy as large as cart-ropes." ${ }^{23}$ The Waldos vehemently denied ever having championed Goodrich. His "frequent visits at our house," they charged, were merely the result of his clumsy attempts to curry their favor. Daniel Waldo insisted that the family had treated Goodrich with the civility due a gentleman and no more; perhaps, he insinuated, Goodrich was unaccustomed to simple respect. The Waldos denied unduly influencing the search committee and haughtily rejected the implication of bribery. ${ }^{24}$ The dissidents also accused the new minister of taking lightly his duties as spiritual shepherd. Goodrich frequently absented himself from the pulpit, they charged, recycled his sermons, ignored the sick, neglected to baptize children, and seldom attended religious conferences. Such a minister, the Waldos and Salisbury concluded, was "unworthy [of] our esteem and confidence." 25

Most important, however, was the role of gender in stimulating and driving the dissent. By tradition, Congregational women had no direct voice in the governance of the church. The selection of ministers, disciplinary proceedings, and questions of doctrine were the unique province of the brethren. The Waldos and Salisbury did not explicitly object to their secondary status, but their acceptance of gender subordination proved contingent upon the minister meeting their definition of ministerial masculinity. The women and the brethren of the First Church agreed that a minister rightfully exercised "paternal watchfulness" over his flock and was to "act as a father and a friend." In return, he could command their deference. ${ }^{26}$ But the middle-aged Waldos and Salisbury found it difficult to accept Goodrich, only twenty-six years old, in this role. Although the Waldos and Salisbury never objected specifically to Goodrich's age, they referred repeatedly to his undeveloped character, a likely synonym for youth. In comparison, the dissenters were close friends with the slightly older Austins. ${ }^{27}$

The Waldos and Salisbury also found Goodrich's style of discourse insufficiently masculine. Accustomed to Austin's trenchant preaching, which was notorious for being "of that sort which permits no hearer to be indifferent," the Waldos and Salisbury described Goodrich's prayers as "cold and heartless" and scorned his sermons as 
"pretty," never "sound, weighty, and impressive." 28 The dissenters criticized what they viewed as Goodrich's "lightness of mind" and "foolish and extravagant conversation," which to them was a mode of expression more suitable to the parlor than the pulpit. Goodrich was "a lover of pleasure more than a lover of God," Daniel Waldo wrote implacably, and was once spied dallying "in a mixed company" when he was supposed to be leading prayer services. ${ }^{29}$ For their part, the Waldo sisters had a reputation for piety and stern sobriety that even family friends found intimidating. Rebekah Dean Salisbury, a cousin by marriage, once described to her sister a friendly discussion of the doctrine of total depravity. Salisbury confessed an admiration for John Locke, prompting her to wonder, "What would the Miss Waldos say to me?"30

At the heart of the ensuing schism was the role these women could legitimately play in their church. Their wealth, their reputation for piety, and their unmarried status placed the Waldo women in an anomalous position: full church members and wealthy taxpayers who nonetheless were excluded from church decision making. As far as the brethren of the First Church were concerned, the problem was nakedly one of the power of wealth: "The peace and harmony of the Society ... . were nothing: the almost unexampled unanimity of the Church and Parish, after such a succession of Candidates, was nothing: the estimation in which Mr. Goodrich was held by neighbouring Pastors and Churches was nothing-so long as they were not gratified." Throughout the dispute, the First Church staunchly maintained that the Waldos' objections "would have sunk into its merited insignificance, had it not been for the money which upheld it." ${ }^{\prime \prime 1}$

Indeed, the dissenters' money was a critical element in the dispute, for had they not been wealthy, the conflict would likely have ended in disciplinary proceedings against the women as "disorderly walkers" for trampling on the covenant. ${ }^{32}$ The covenant was the theological and constitutional foundation of the decentralized Congregational churches; by owning the covenant, church members signified their acceptance of the authority of the congregation to pass judgment on their spiritual lives. In theory, the church was a gathering of spiritually equal souls; in reality, this authority was reserved for the brethren alone. By withdrawing from worship and refusing to accept the "decisions of Providence" that had been manifested by the election of the Reverend Goodrich, the women repudiated the presumption of male authority and, in essence, denied that the brethren spoke for God ${ }^{33}$ In this contest over who rightfully exercised power within the First Church, the women's wealth gave them a measure of power other women could not wield, frustrating attempts to discipline them. ${ }^{34}$ 
Unwilling or unable to take seriously the women's protest at their exclusion, the First Church brethren insisted that the dispute was fundamentally a question of the control of the majority by a wealthy minority. Moreover, the First Church was forced to focus on the issue of money because the Waldos and Salisbury had comported themselves impeccably. Not for them the fate of Betsey Flagg of neighboring Boylston, Massachusetts. In 1814, Flagg expressed her dissatisfaction with the pastor of her church "in an improper and injudicious manner $\&$ in a way calculated to irritate and offend," thus shifting the discussion from the minister's conduct to her own. An ecclesiastical council, of which Samuel Austin was a member, successfully mediated the dispute, but not before requiring that Flagg apologize to the offended Boylston brethren. ${ }^{35}$ In sum, the schism of the First Church occurred with the two sides fighting different battles: for the dissidents, the issue was a question of gender, the right of women to decide their religious futures; for the First Church, the issue was a question of democracy, the right of the (male) voting majority to decide the future of the church. ${ }^{36}$

Throughout 1817 and into 1818, a stalemate ensued as Goodrich solidified his position, conducting a revival that brought eighty new members into the church and organizing its first Sunday School. ${ }^{37}$ Confident of his support, Goodrich denounced his detractors from the pulpit. The Waldos sat in the family pew silently fuming while Goodrich "frequently pointed at us in his publick discourses." The tension broke one Sunday in the spring of 1818, when Goodrich addressed the congregation on the "nature and obligations of their Christian vows," which, he explained, required all to accept meekly the discipline imposed by the church. Certain that the sermon was intended as a public rebuke, the Waldos had had enough. Joined by Salisbury, they stalked out of the church and went to worship with the Baptists, whose services the Waldo sisters and Salisbury had taken the precaution of observing. There the dissidents "felt much happier than at our own meeting-house. ${ }^{\prime \prime 3}$ A week later, Daniel Waldo ran for reelection to the state senate, and the stones flew.

During the summer the dispute took a new turn when the lawsuit over ministerial lands was finally settled. The church prepared to dismiss Austin and promote Goodrich to full pastor, a role he was, for all practical purposes, already performing. But Austin was unhappy in Vermont and proposed that he return to the Worcester pulpit, since he was, technically, still its senior pastor. Seizing upon the opportunity to rid themselves of the despised new minister, the Waldos and Salisbury organized a campaign for Austin's return. Austin actively encouraged them, informing the First Church that he 
would accept dismissal only if "a large proportion of the Church" requested it and if they "assign sufficient reason therefore." Austin also stepped up the pressure upon the church by demanding a mutual council to arbitrate his claim, as was his right under Congregational church rules. ${ }^{39}$

The council, composed of five clergymen jointly agreed upon by Austin and the church, met the following November. A proGoodrich majority report submitted to the mutual council pointed out that Austin had left willingly and that Goodrich had been properly installed. The lack of a formal dismission was due to the novel complication of Austin being a party in the lawsuit, which did not fundamentally alter the circumstances. The council also read a pro-Austin minority report that sought to return Austin and, in effect, to fire Goodrich. The minority relied largely upon a legalistic argument: they wanted Austin for their shepherd, he wanted them for his flock, he was still the senior minister, and, to their minds, he had done nothing to merit dismissal. ${ }^{40}$ However, the mutual council was persuaded by the principle of majority rule and by a determination to uphold ministerial authority and "strengthen the hands of him that is set over [you] in the Lord." In December 1818, it formally dissolved Austin's connection to the First Church and ordered the dissidents to "return to the stated ministrations of their worthy Pastor." The mutual council concluded its report with a prophetic warning against the likely outcome of continued dissension: "It is to be feared you may plunge into a series of difficulties, of which we cannot see the issue. You may lay a foundation for dissensions and evils which may extend to generations yet unborn. Remember, you are acting for yourselves, and not for us." ${ }^{\prime 41}$

The council's decision forced the dissenters either to admit they were wrong and return to the First Church or to go elsewhere. The Waldos and Salisbury took temporary respite with the Baptists but were soon journeying to Boston's Old South Church, eight hours away by stagecoach. This solution was untenable in the long term, and, unwilling to yield to the First Church, the dissidents resolved to form a church of their own. As a first step, Rebecca Waldo, Sarah Waldo, and Elizabeth Salisbury sought dismissions and recommendations from the First Church, the process by which individuals transferred their membership from one Congregational church to another. ${ }^{42}$ To forestall their leaving, a subdued Goodrich wrote to Salisbury with "the most pacific views" to request "a personal and friendly interview" to persuade her to remain. ${ }^{43}$ When Salisbury refused to meet with him, Goodrich and the First Church dismissed the dissidents but did not recommend them, a very public declaration that the 
dissenters were not worthy Christians. The First Church thus formally censured the female dissenters for their impertinence in passing judgment upon the minister and for repudiating the male church authorities.

Rebecca Waldo, Sarah Waldo, and Elizabeth Salisbury were not about to tolerate any further humiliation at the hands of Goodrich and the First Church. These women were full church members, that is, each had undergone conversion and experienced the saving grace that only an omnipotent God could bestow. Their conversions had assured them of their spiritual worth and equality, for none but God was qualified to judge them. Moreover, because their identity and claim to social status were linked to their reputations for piety, the First Church's refusal to recommend them struck at the heart of who they considered themselves to be. In a petition to the First Church, the Waldos and Salisbury demanded, "Are the Church, who have witnessed the constancy, cheerfulness, and solemnity with which the disaffected have heretofore attended with them, on the duties of publick worship, prepared to question their sincerity, and denounce their repeated avowals, as assumptions, affectations, and hypocrisy?" They insisted that the church must "hold us blameless.-We say blameless." The Waldos and Salisbury were women of considerable means, largely free to govern themselves. When the minister dared to bring them to heel, their consciences, and likely their pride, compelled them to rebel. ${ }^{44}$

To a woman, the Waldos and Salisbury denounced Goodrich and the First Church and unequivocally asserted their right to determine for themselves their religious fates. If they were uneasy with the new minister, they implied, it must be he who was at fault. Trusting in their "feelings and the impressions which have been made on our minds," the Waldo sisters explained in a joint letter to the First Church that under Goodrich they had "failed of receiving . . religious satisfaction, comfort, and improvement." With a nod toward the majority, they conceded that their opinions might seem erroneous to some but declared frankly that "still [our opinions] are real and fixed in our minds" and were not going to change. It was a duty they owed to themselves as Christians, the women argued, to seek "comfort and happiness" where they could find it. ${ }^{45}$

Elizabeth Salisbury concurred with the Waldos in a separate petition to the church. To Salisbury, the fiery Austin had been "a burning and a shining light." Salisbury explained that Goodrich lacked Austin's passion and, thus, to her mind, Austin's devotion. She granted that her assessment might be subjective but maintained that such was "not now the question: it is sufficient that [my objections] have 
prevented me from receiving that improvement and edification from attendance on publick worship, which are the ends of its institution." The new minister had failed to uplift and enlighten her, Salisbury declared, and, "rather than . . trifle with holy time," she would do as she deemed fit. ${ }^{46}$

The Waldos and Salisbury followed up their individual petitions with a joint statement to the First Church reiterating and elaborating upon their views. After demurely reminding the church how "painful ... it must be to females to submit their religious sentiments to the animadversions of contending parties," they went on the offensive. Goaded by the church's repeated attempts at "solemn expostulation, if not of admonition," the women articulately attacked their critics. They unequivocally rejected the authority of the minister and the deacons to dictate to full church members and maintained that only they themselves were qualified to judge their own minds. It was the privilege and the obligation of all Christians, they argued, to trust their consciences: "of our own happiness and afflictions, of our own enjoyments, sufferings and trials, and of the means of promoting them, especially of a religious nature, we are, and from necessity, must be, the best judges." As the church knew well, they stated, Christian introspection "can never be performed by substitutes, or yielded to any other person." According to Sarah Waldo, Rebecca Waldo, and Elizabeth Salisbury, what was at stake was their inalienable right to religious autonomy in the face of a tyrannical majority. ${ }^{47}$

The three then launched a multipronged offensive against the churchmen who were trying to discipline them. They began by insisting that the mutual council's decision to uphold Goodrich's pastorship cast in doubt its "wisdom, foresight, affection, and sincerity." How could its verdict be just, the dissenters demanded, when they had been "condemned . . . unheard, undefended, and even unapprized of the process against them." In fact, the Waldos and Salisbury could hardly have been "unapprized" of the actions of the mutual council. Such a statement may have been a way to emphasize their sense of grievance, but it also reflected their disdain for a court of appeal in which only men participated and controlled and from which they, as women, were excluded. ${ }^{48}$

The real issue, it seemed to the women, was not whether they had acted improperly but whether others had. In the process, they attempted to recast the debate by protesting the efforts of a majority to transgress the rights of a disempowered minority. Turning the argument in a new direction, they accused the male First Church authorities of silencing righteous opposition. The women lay claim to the liberty to "decide on our own hearts," just as "all others [enjoy] 
the free exercise of the rights of their own consciences." Did the First Church have the right to use Congregationalism's "Law, Constitution and Platform" to "support its measures, however intolerant, illiberal and severe they may be?" The women concluded: "We are informed otherwise." A religious minority, they insisted, was entitled to rely upon "the perceptions and affections of [their] heads and hearts," which, after all, were "the vitals of religion and piety." The women insisted that natural law, "a law paramount to all other laws" because it was "impressed by the finger of God," superseded the human law and granted them freedom of thought and action. True religious principles, they asserted, had to be "spontaneous, self-efficient, voluntary, unforced, uncorrupted, and unawed by foreign energies." The women's assertion of the right to dissent had thus developed into a declaration of religious independence from the authority of the First Church. ${ }^{49}$

The Waldos and Salisbury did not explicitly link their criticisms of church authority with a protest against women's subordination. Yet, the arguments they marshalled presumed a position of equality in the church, as did their refusal to accept the decisions of the church leaders. Moreover, by registering dissent as Christians, rather than as Christian women, they implicitly repudiated religious distinctions based on gender. Although only men held positions of formal leadership in Congregational churches, it does not follow that women had no say in church decisions, particularly where they formed a majority of full church members. Still less does it suggest that religious women accepted without question or protest the decisions of male church leaders. In Worcester's First Church, the Waldos and Salisbury reserved the right to veto church decisions with which they did not agree, and they repeatedly refused to recognize the authority of a minister whom they neither supported nor respected. For the Waldos and Salisbury, the church was an assembly of believers whose power was contingent upon the voluntary submission of each member. This submission could be justly withdrawn if, in the mind of an individual, the congregation strayed from the path of righteousness.

Economically independent, clearly well-educated, and the daughters of families of standing, the Waldos and Salisbury were accustomed to deference from those around them, male and female, clergy and laity, and were well armed to assert and defend their autonomy. At their insistence, a second ecclesiastical council met, overruled Goodrich and the First Church, and granted the recommendations that restored to the Waldos and Salisbury their status as good Christians. Now free to transfer to a church of their choice, the dissidents found none to their liking. Pointing out that "none of us can en- 
joy the ordinances of the Gospel with convenience; and some of us can no longer enjoy these ordinances at all," the dissidents elected to found a new church. ${ }^{50}$ In May 1820, over the strident objections of the First Church, yet another council of ministers met to consider whether to convene the "come-outers" as a regular church. The rancor within Worcester's First Church was "most delicate and interesting," the council noted diplomatically, and appeared to permit of no compromise. It seemed best for the peace of religion to accommodate the desire for independence. The council was also reassured that the comeouters were "able and disposed to support publick worship by themselves." After scrutinizing the proposed church's Articles of Faith and Covenant for conformity to orthodox Congregational tenets, the council unanimously pronounced the dissidents no longer outcasts from the First Church but "a regular Ch[urc]h of Christ," the Calvinist Church of Worcester. The council ended its report by beseeching Worcester's faithful to halt the internecine squabbling: "Brethren, be of one mind; live in peace, and the God of love and peace be with you. ${ }^{\prime 51}$

Four years after the onset of strife within the First Church, the dissidents were officially sanctioned as the Calvinist Church of Worcester. The Waldo sisters and Elizabeth Salisbury had led a rebellion against established authority and had rejected the officially sanctioned governance of their minister. Not only did they successfully defend their religious independence, but they were also able to remain within the Congregational church. The forces of heterodoxy had transformed the church of the Puritans, which two centuries earlier had tried and banished Anne Hutchinson for criticizing the clergy. It was now more accepting of the demands of individual conscience, even from women. Moreover, the Worcester dissidents enjoyed a degree of self-confidence that enabled them to stare down their opposition. Their faith granted them equality, their conversions fortified them with conviction, and their wealth accustomed them to independence. In 1820, they left the church where they had worshiped for many years, where they had experienced God's saving grace, and built another.

In view of the acrimony that preceded the split, it was not to be expected that the parties involved would easily follow the ecclesiastical council's plea for harmony. Still, the degree of the First Church's continuing animosity is striking. The old church scorned the council's decision. It insisted that the Calvinist Church was not a true church, and it refused to dismiss and recommend First Church members to it. Samuel Austin, watching the events from a distance, exaggerated only slightly when he accused the First Church of engaging in 
"zigzag proceedings" that were "entirely unprecedented and unwarranted." As the council itself had acknowledged, the dissidents had not, after all, done anything wrong. Since the council of 1820 had accepted the Calvinist Church into the fellowship of Congregational churches, the First Church could not justly refuse to dismiss and recommend its members to it. And yet it did. As Austin queried, "Cui bono?"52

The belligerence between Worcester's two orthodox Congregational churches continued into the 1820's, when it became clear that most of those seeking to transfer to the new church were women.$^{53}$ It was bad enough when extraordinary women, such as the unmarried and moneyed Waldos and the enormously wealthy Salisbury, led the attack on Goodrich. It was worse still when they successfully thwarted the First Church's determined attempts to discipline them and founded a new church. But it was intolerable when other women followed their example and began to exercise their spiritual autonomy by daring to pass judgment on the church's leadership, thereby rejecting the presumption of female submission to the male church hierarchy.

The crosscurrents of gendered beliefs and loyalties were played out in the cases of Anna McFarland and Lydia Taylor. In asserting their independence from the religious authority of the First Church, McFarland and Taylor opposed the actions of men whom they believed had wandered from the path of Christian righteousness. They, too, claimed the right to assess and, ultimately, to reject the ability and effectiveness of the minister. Through his own intransigence and that of his congregation, the Reverend Goodrich unwittingly provided the opportunity for female parishioners to reject the spiritual authority of men and to enact the spiritual autonomy of women.

William McFarland, a well-to-do farmer, and Samuel Taylor, a clockmaker, were among the original subscribers of the Calvinist Church. Both were church trustees; Taylor was also a deacon. In the fall of 1820, their wives, Anna McFarland and Lydia Taylor, wrote to the First Church respectfully requesting dismissions and recommendations to the Calvinist Church on the grounds that they wished "to become members of the same church to which our husbands belong." ${ }^{54}$ The request touched off a storm of controversy, for McFarland and Taylor had raised a thorny issue: what should a pious Christian woman do when confronted with conflicting patriarchal claims upon her loyalty, one from her husband and the other from her church?

The Protestant churches prized the religious unity of married communicants, both by doctrine and by tradition. To the orthodox, 
marriage embodied divinely ordained gender relations and justified and strengthened the patriarch's position in society as the head of a family. More prosaically, couples were a boon to a church's financial status. The disestablishment of Congregationalism compelled parishes to become self-supporting, but because churches maintained the traditional tax structure, only heads of households were liable for the church tax. Thus, a married woman whose husband did not attend her church was not taxed for its support, and her membership, while spiritually vital, was less likely to be economically helpful. Only when a woman was widowed was she reclassified as a head of household, becoming a church taxpayer. Even then, however, the poverty or reduced circumstances that all too often accompanied widowhood limited the contributions of most women to the church coffers. ${ }^{55} \mathrm{At}$ the same time, ministers were increasingly judged by the number of converts won and sustained. The loss of a communicant to death or resettlement was no reflection upon a minister; not so his or her removal to the church across the Common. It would be especially galling, we might imagine, if the rival church belonged to the same sect. Churches and ministers thus had both practical and theological reasons to respect and to foster the religious unity of married communicants. The financial health of the church depended upon the fidelity of its congregation, while the minister's reputation was built upon a demonstrated respect for his ability and authority.

Such was the dilemma facing Charles Goodrich upon receiving McFarland and Taylor's petition for a dismission and recommendation to the Calvinist Church. Hesitant to encourage wives to disregard the divinely sanctioned authority of their husbands, yet unwilling to lose two parishioners to the despised new church, the minister trod a fine line by simultaneously acknowledging the women's dilemma while rejecting their solution. He began by commending McFarland and Taylor on their conscientious efforts to do what was right. The church "must highly respect" the women's desire to worship with their husbands, Goodrich wrote, for marriage was a sacred relationship "of a nature most tender." Still, though he praised a proper "regard for your Husbands," Goodrich declared that the Calvinist Church was not "a regularly formed Church of our Lord Jesus." The new church was, Goodrich insisted, a direct assault upon the order and discipline of the Christian community, and he forbade their transfer to the Calvinist Church. Should McFarland and Taylor persist, he wrote, "this Church will consider you as ... cutting yourselves off from the priviledges [sic] of Members of the Church." In sum, Goodrich argued that a Christian woman's obligation to her soul took precedence over her social (and legal) obligation to her husband. A 
woman who did not assert herself to defend her spiritual autonomy risked excommunication and eventual damnation. ${ }^{56}$

Goodrich's ultimatum forced McFarland and Taylor to decide whether to follow their minister or their husbands; they could not do both. Shortly after receiving Goodrich's letter, they asked that the Calvinist Church accept them as full members. In this petition, they made no mention of their desire to worship with their husbands but instead professed their devotion to the orthodoxy of the new church. "The First Church is divided," they explained, "and our views and feelings are with that part, which have taken the name of the Calvinist Church." The new church, predictably, promptly received them. ${ }^{57}$

The McFarland and Taylor controversy suggests the means by which orthodox Congregational women could be brought to act upon the possibilities inherent in their spiritual autonomy. It seems likely that McFarland and Taylor anticipated that a request to transfer would excite a conflict-in light of the ongoing hostility, it would have been naive for them to believe otherwise-and their first impulse was to deflect trouble by relying upon the shield of patriarchal gender relations. They thus justified their request by insisting that they wished to follow their husbands, as a good wife should. But Goodrich rejected this argument and urged the women to act independently. For the sake of their souls, he commanded them to follow him, repudiate the ruling of the ecclesiastical council, and defy their husbands. Obliged to be decisive, McFarland and Taylor spurned their minister. They declared that their Christian consciences would properly guide them and made their choice based upon their "views and feelings."

The situation confronting McFarland and Taylor was increasingly common as the number and kinds of Protestant denominations proliferated in the first half of the nineteenth century. But whereas McFarland and Taylor followed their husbands, other women made other choices. Elizabeth Salisbury, for example, left the First Church to organize the Calvinist Church even while her husband and son continued to worship with the liberal Unitarians. Between 1820 and 1830, sixteen married couples joined the Calvinist Church as full church members (including the McFarlands and Taylors). The total number of new church members in this decade was 108, including 62 females and 46 males. It is likely that most of these were adults and also that they were married. If so, then slightly less than 30 percent of the members of the Calvinist Church worshiped alongside their spouses, while slightly more than 70 percent did not. Of those who did not share their religious lives with their spouses, 46 , or 60.5 percent, were women; 30, or 39.5 percent, were men. Especially in churches torn by 
dissent, the decision of church membership was more than a manifestation of a culturally prescribed feminine piety; it was an assertion of women's autonomy from the dictates of the male church hierarchy. ${ }^{58}$

One final area of church organization offers further evidence of the often convoluted nature of women's role in the antebellum churches. As we have seen, churchwomen had no official part in the selection of ministers. The charter of the new Calvinist Church explicitly reserved the right to "elect ordain and settle" a minister to the men of the congregation, three-fourths of whom had to agree upon a candidate. There was, however, an exception to the rule of men: the charter specifically granted to the Waldo sisters the right to nullify ministerial elections. The Waldos do not seem to have exercised their unique veto power, although it might not have been necessary for them to do so. Daniel Waldo sat on all ministerial search committees and presumably would have gained his sisters' prior approval of candidates. $^{59}$

But the Waldos were not the only women of the church to have a voice in the selection of the minister. Despite the charter's limiting clause, women voted in every ministerial election in the Calvinist Church during the antebellum period. The church's first election in 1823 set the precedent when the women joined the men in standing to show their unanimous support for the Reverend Loammi Ives Hoadley. The women's endorsement was thereafter sought for all new ministers. The extension of the vote to the women of the church provoked no recorded comment or criticism; nor do church records indicate when the decision was made or by whom. While such an act did not violate church laws or covenants, it was a decided break with tradition. Moreover, while some men occasionally voted against confirmation, the women invariably voted unanimously to confirm the choice of the male search committee. ${ }^{60}$

The meager evidence of women's voting in the Calvinist Church suggests at least two contrary interpretations. On the one hand, the extension of the vote to the women of the church, as well as their tendency to vote as a bloc, may indicate that women wielded real power in the decisions of a church in which they were a decided majority. Only men sat on the search committees, and only men negotiated the terms of settlement. But the women of the church had numerous informal opportunities to air their criticisms and to express their preferences during the lengthy search process, which required candidates to meet with the parish and to audition for the pulpit by delivering sermons, often over a period of several months. The women's unanimous support for successful candidates may thus reflect extensive lobbying that eliminated unacceptable applicants prior to 
the final vote. On the other hand, it is possible that the churchwomen's sanction of ministers was purely perfunctory, essentially a hollow affirmation of a choice that had already been made by the men.

Still, at a time when American politicians were extending the suffrage to most white men but expressly not to women, it is significant that churchwomen voted at all and that they did so alongside the men. Moreover, the women's vote was considered sufficiently formal for the tally to merit inclusion in the church records. Women's participation in these ministerial elections likely was a result of the fledgling church's history. The belief that a religious community existed only with the declared consent of each member, male and female, had been the justification for the formation of the Calvinist Church. In their petitions protesting the actions of the First Church, the Waldos and Salisbury defended their rejection of Charles Goodrich by asserting that, since they had not given their consent to his election, they were not bound by his authority. The church these women founded sought to avoid the same mistake and thus required all members of the congregation to participate formally in the choice of minister. At the very least, the congregation acknowledged women's right to help decide the future of the church and demonstrated confidence in women's ability to vote wisely. Orthodox Congregational churches could thus be more democratic in practice than they appear in principle.

In the early nineteenth century, New England's Protestant churches were important centers of community life in which women were the majority and men the minority. The breakdown of the church of the Puritans, as well as the proliferation of religious alternatives, offered unprecedented opportunities for devout women. The question was no longer when, or if, one experienced conversion, but also within what church and on whose terms. The much-noted feminization of religion resulted not simply from women's numerical dominance, for women had long been the majority of church congregations; nor can it be inferred primarily from the more sentimental religious expression of the Second Great Awakening, for both men and women were drawn to the New Measures. Rather, religion was feminized when disestablishment confronted pious women with an unprecedented freedom and necessity to choose. It was this new ability and requirement to express themselves that gave force and meaning to women's numerical majority.

The Worcester schism illustrates how the ability of a few wealthy women to contest the selection of a minister served as an opening wedge in cracking men's control of church affairs, setting a precedent that less privileged women could follow. The travails of the beleaguered Charles Goodrich thus demonstrate that, in an era of 
theological controversy and increased religious options, male church authorities had to earn the respect of the women of the church. A preacher who failed to grasp this lesson could find his ministry-and, potentially, his masculinity-assailed as "pretty" and unimpressive. The founding of the Calvinist Church also suggests that pious women did not shy from challenging male church authorities when confronted with what they perceived to be a threat to religious orthodoxy. Dissenting women drew upon their acknowledged spiritual equality to criticize, even disparage, the governance of a minister whom they did not respect. Their actions strengthen the argument for the feminization and democratization of New England Protestantism, not just in terms of theology and numbers of converts but also in practice.

In the nineteenth century, a variety of dissenting religious movements experimented with redefining gender roles. Mainstream denominations were similarly engaged in social change, and religious women were vital to these efforts. New England's churches often served as centers for the gathering of like-minded women, who founded voluntary societies to take aim at righting a myriad of social wrongs in the name of Christian justice. The feminization of religion contributed to this effort by reinforcing women's acknowledged spiritual autonomy. The founding of the Calvinist Church of Worcester thus reminds us that orthodox Congregational women were active in analyzing and transforming the role of women in nineteenth-century American religion and society.

\section{Notes}

1. Elizabeth Tuckerman Salisbury to Stephen Salisbury, April 7, 1818, Salisbury Family Papers, box 18, folder 3, Manuscript Collection, American Antiquarian Society, Worcester, Massachusetts (hereafter cited AAS); Susan M. Meyer, The Salisbury Family Mansion: A Plan for Furnishings (Worcester, Mass.: Worcester Historical Museum, 1986).

2. Elizabeth Tuckerman Salisbury to Stephen Salisbury, April 7, 1818.

3. Ibid. The raid on his foliage was a personal affront to Waldo, a patron of the Massachusetts Agricultural Society, an early promoter of the Worcester Agricultural Society, and a supporter of local cemetery beautification. See the letter from J. N. Lorrell of the Massachusetts Agricultural Society to Daniel Waldo, February 2, 1818, Waldo Family Papers, box 2, folder 3, Manuscript Collection, AAS; William Lincoln, History of Worcester, Massachusetts (Worcester, Mass.: Moses D. Phillips, 1837), 325-26; and Levi Lincoln's Memorial to Daniel Waldo, July 9, 1845, Waldo Family Papers, box 2, folder 5. 
Waldo, a Federalist, was elected to the Massachusetts State Senate in 1816 and served three consecutive one-year terms. According to the family, Waldo declined renomination in 1819. Less sympathetic sources insisted Waldo knew he would not be renominated. See Lincoln's Memorial to Waldo; Worcester National Aegis, April 8, 1818, and March 10, 1819; and Worcester Spy, April 8, 1818.

4. Elizabeth Salisbury to the First Church, undated but January 1819, in Origin and Progress of The Late Difficulties in The First Church in Worcester, Mass. (Worcester, Mass.: Manning and Trumbull, 1820), 33 (hereafter cited as Origin).

5. For the feminization of American Protestantism, see Barbara Welter, "The Feminization of Religion in Nineteenth-Century America," in Clio's Consciousness Raised: New Perspectives on the History of Women, ed. Mary Hartman and Lois Banner (New York: Harper Torchbooks, 1973), 137-57; Nancy F. Cott, "Young Women in the Second Great Awakening in New England," Feminist Studies 3 (Fall 1975): 15-29; Nancy F. Cott, The Bonds of Womanhood: 'Woman's Sphere' in New England, 1780-1835 (New Haven: Yale University Press, 1977); Richard D. Shiels, "The Feminization of American Congregationalism, 1730-1835," American Quarterly 33 (Spring 1981): 46-62; Mary P. Ryan, "A Woman's Awakening: Evangelical Religion and the Families of Utica, New York, 1800-1840," American Quarterly 30 (Winter 1978): 602-23; Mary P. Ryan, Cradle of the Middle Class: The Family in Oneida County, New York, 1790 1865 (New York: Cambridge University Press, 1981), 83-109 and Appendix C, 257; and Harry S. Stout and Catherine A. Brekus, "Declension, Gender, and the 'New Religious History,'” in Belief and Behavior: Essays in New Religious History, ed. Philip R. VanderMeer and Robert P. Swierenga (New Brunswick, N.J.: Rutgers University Press, 1991), 15-37. In The Feminization of American Culture (New York: Alfred A. Knopf, 1977), Ann Douglas argues that the feminization of religion extended to the feminization of American culture when middle-class educated women, disestablished by their gender, joined forces with ministers, disestablished by disestablishment, to produce a sentimental mass culture. In a critique of Douglas, David Schuyler found little evidence for this thesis, arguing that the relationship between ministers and their congregations needs more thorough analysis before the feminization argument can substantiated. See David Schuyler, "Inventing a Feminine Past," New England Quarterly 51 (September 1978): 291-308.

6. For the democratization of Protestantism, see Sydney E. Ahlstrom, A Religious History of the American People (New Haven: Yale University Press, 1972), 387-509; and Nathan O. Hatch, The Democratization of American Christianity (New Haven: Yale University Press, 1989).

7. Genevieve McCoy, "The Women of the ABCFM Oregon Mission and the Conflicted Language of Calvinism," Church History 64 (March 1995): 62-82, quote from 64. 
8. Susan Juster, Disorderly Women: Sexual Politics and Evangelicalism in Revolutionary New England (Ithaca, N.Y.: Cornell University Press, 1994), 12. Catherine A. Brekus also finds that the establishment of formerly dissenting churches sparked pressure to limit women's religious leadership and autonomy. See Catherine A. Brekus, "'Let Your Women Keep Silence in the Churches': Female Preaching and Evangelical Religion in America, 1740-1845" (Ph.D. diss., Yale University, 1993). See also the collection of essays in Catherine Wessinger, ed., Women's Leadership in Marginal Religions: Explorations Outside the Mainstream (Urbana: University of Illinois Press, 1993).

Terry D. Bilhartz argues against the feminization model, although for different reasons, in "Sex and the Second Great Awakening: The Feminization of American Religion Reconsidered," in Belief and Behavior, ed. VanderMeer and Swierenga, 117-35. David S. Reynolds proposes that feminization was paired with religious "masculinization" in the form of a "muscular Christianity" in "The Feminization Controversy: Sexual Stereotypes and the Paradoxes of Piety in Nineteenth-Century America," New England Quarterly 53 (March 1980): 96-106. Reynolds' argument is supported by Paul E. Johnson and Sean Wilentz in their study of the antebellum New York cult of Matthias, The Kingdom of Matthias: A Story of Sex and Salvation in Nineteeth-Century America (New York: Oxford University Press, 1994). Johnson and Wilentz suggest that the appeal for some men of the Prophet Matthias lay in his reassertion of patriarchal authority in the face of a feminized evangelicalism. Johnson and Wilentz do not, however, analyze why some women found this message appealing.

9. The case for feminization has largely relied on the numerical dominance of women in the churches as well as the emotionalism of the Second Great Awakening. The first contention was true as early as the seventeenth century, when no such conclusion of feminization is asserted. See, for example, Cott, The Bonds of Womanhood, 126. The second contention is questionable, since the emotionalism of the revivals appealed to men as well as to women; indeed, the "new measures" of Charles Grandison Finney were expressly intended to remind men (and women) of the necessity of setting aside earthly cares for spiritual concerns. See Charles Grandison Finney, "Measure to Promote Revivals," in Lectures on Revivals of Religion by Charles Grandison Finney, ed. William G. McLoughlin (Cambridge: Harvard University Press, 1960), 250-76.

10. By the 1840 's, Worcester was the center of numerous railroad lines and a favored site for political and social conventions in the antebellum era, including the first national women's rights convention. Its citizens also participated actively in the region's political, social reform, and religious movements. For secondary works on Worcester politics and economics, see, for example, John L. Brooke, The Heart of the Commonwealth: Society and Political 
Culture in Worcester County, Massachusetts, 1713-1861 (New York: Cambridge University Press, 1989); and Robert Doherty, Society and Power: Five New England Towns, 1800-1860 (Amherst: University of Massachusetts Press, 1977).

While no community may accurately be said to reflect all others, an argument for Worcester's suitability as a test case for the feminization thesis can be made. Neither large nor small, rural nor urban, old nor new, Worcester shared many of the characteristics of developing towns in New England and New York, the areas most affected by the Second Great Awakening and the areas usually cited in studies of feminization. Most important, however, Worcester is especially well suited for such an analysis due to the unusually rich local history collections at the American Antiquarian Society (AAS). Founded in Worcester just as the crisis in the First Church began, the extensive church records available at the AAS permit the kind of close institutional analysis necessary to test the feminization thesis.

11. Indeed, conflicts between ministers and their congregations were so common in the early years of the nineteenth century that they earned the sobriquet "difficulties." For the evolution of American religion generally, see Ahlstrom, A Religious History of the American People; Edwin Scott Gaustad, A Religious History of America (New York: Harper and Row, 1966); William G. McLoughlin, Revivals, Awakenings, and Reform: An Essay on Religion and Social Change in America, 1607-1977 (Chicago: University of Chicago Press, 1978); and William G. McLoughlin, New England Dissent, 1630-1833: The Baptists and the Separation of Church and State, 2 vols. (Cambridge: Harvard University Press, 1971).

12. Daniel Waldo often spoke for the women in the early stages of the dispute; however, because he was not a full member of the First Church but only a member of the parish, he was not a party to the subsequent proceedings against the dissidents. A third Waldo sister, Elizabeth, eventually joined the Calvinist Church but does not seem to have been involved in the quarrel with the First Church. None of the Waldos ever married; they lived together in the Waldo mansion on Main Street.

13. In 1827, the Calvinist Church assessed the estate of each Waldo sister at $\$ 35,500$; when they died two decades later, each was worth about $\$ 50,000$. In 1846 , Elizabeth Salisbury controlled an estate of $\$ 125,200$. The bulk of her husband's estate went to their son, Stephen Salisbury II, whose property in 1846 was assessed in excess of $\$ 320,000$. See Central Church Records, folio vol. "W," vol. 4, Manuscript Collection, AAS (by the 1830's, the Calvinist Church was known as the Central Church); Papers of Daniel Waldo, Waldo Family Papers, box 2, folders 3-5; and List of Persons Assessed in the Town of Worcester, for the Town and County Tax (Boston: Samuel N. Dickinson, 1846), 30, 31, 34. 
14. Edward Pessen has estimated that, in the antebellum era, owning property worth in excess of $\$ 50,000$ placed an individual in the top 1 percent of the population. Edward Pessen, Riches, Class, and Power before the Civil War (Lexington, Mass.: D. C. Heath, 1973), 36.

15. For discussion of the theology of the New Divinity ministers, see Ahlstrom, A Religious History of the American People, 403-14. For Samuel Austin, see Lincoln, History of Worcester, 157-61; William B. Sprague, Annals of the American Pulpit, 9 vols. (New York: R. Carter and Brothers, 1857; repr., New York: Arno Press, 1969), 1:221-26; and Leonard Bacon, A Historical Discourse Delivered at Worcester, in the Old South Meeting House, September 22, 1863; The Hundredth Anniversary of Its Erection (Worcester, Mass.: Edward R. Fiske, 1863), 12. In the 1790's, Worcester's First Church, which had long endorsed the Halfway Covenant, agreed to renounce it if Austin would be their pastor. See Sprague, Annals of the American Pulpit, 1:223.

16. The town decided in favor of the Unitarians, but the courts eventually ruled in favor of the First Church. See Charles Evans Butler, Walking in the Way: A History of the First Congregational Church in Worcester, 17161982 (Worcester, Mass.: The Society, 1987), 69-70, 72-74. For the disestablishment of Congregationalism in New England, see McLoughlin, New England Dissent, 2:1065-1274.

17. Letter from the "qualified voters" to the Assessors of the First Parish, July 1, 1816, Old South Church Records, box 1, folder 10, AAS. The First Church was also known as the Old South Church.

18. Origin, 4. Origin recounts the First Church's version of events.

19. McLoughlin, New England Dissent, 1:661, 2:1102. On the question of disestablishment, see also William G. McLoughlin, Soul Liberty: The Baptists' Struggle in New England, 1630-1833 (Hanover, N.H.: University Press of New England, 1991), 293-301. David Schuyler highlights the significance of church taxation and suggests that who paid the minister's salary was pertinent to the question of feminization. The findings from Worcester support Schuyler's insight that, with or without state sanction, church taxpayers, as opposed to church members, would have a disproportionate influence over the minister. See Schuyler, "Inventing a Feminine Past," 298.

20. See editor's note, Remarks on the Late Publication of the First Church in Worcester, of Which the Rev. Charles A. Goodrich Was Pastor, Relative to the "Origin and Difficulties" in That Church (Worcester, Mass.: Manning and Trumbull, 1821), 121 (hereafter cited as Remarks). The pamphlet was the dissidents' response to Origin. The quotation is from from Origin, 9.

21. The first ministerial candidate had been vetoed by opposition orchestrated by the Waldos. See Origin, 4. 
22. Origin, 4-5; Butler, Walking in the Way, 73. Daniel Waldo never became a member of the church, that is, he did not undergo conversion. However, as a member of the parish, he participated actively in church affairs, served frequently on church committees, and could vote in parish meetings. See Remarks, 9.

23. Remarks, 9 (emphasis in original). The origin of this accusation is suggested in Goodrich's later introduction to a book by a sixteenth-century English dissenter, in which Goodrich, a student of history, criticized Calvin's rigid rule of Geneva. Calvin's "rude and fierce soldiery" against "popery," Goodrich asserted, led him to abolish "many most useful laws and practices ... merely on account of their adoption by the church of Rome." Goodrich deemed Calvin's zealotry regrettable and no longer necessary. Opinions such as these perhaps prompted the "cart-ropes" remark that so scandalized the Waldos. Charles A. Goodrich, ed., Actes and Monuments of the Church: Book of Martyrs, or, A History of the Lives, Sufferings and Triumphant Deaths of the Primitive as Well as Protestant Martyrs: From the Commencement of Christianity, to the Latest Periods of Pagan and Popish Persecution (New York: William W. Reed, 1831), 47-48.

24. Remarks, 7-12; Daniel Waldo to the First Church, December 20, 1820, in Remarks, 8.

25. This assessment of Goodrich can be found in Remarks, 7; see also 26-27. The quotation is from ibid., 7. Elizabeth Salisbury concurs with this assessement in her letter to the First Church, undated but January 1819, in Origin, 32-33.

26. Minority report to the Ecclesiastical Council, December 1818, cited in Origin, 19-20.

27. In 1816, Daniel Waldo, at fifty-three, was the eldest of the dissidents; Sarah Waldo was forty-nine, Elizabeth Salisbury was forty-eight, and Rebecca Waldo was forty-five. See Waldo Lincoln, Four Generations of the Waldo Family in America (Boston: David Clapp \& Son, 1898); and Daniel Waldo to Charles A. Goodrich, April 29, 1817, Old South Church Records, box 1, folder 10. Samuel Austin, fifty-seven years old in 1816, had been a minister since 1784; he came to Worcester in 1790. For the relations between the two families, see the letter from Jerusha Hopkins Austin to Elizabeth Salisbury, April 18, 1818, Salisbury Family Papers, box 18, folder 2; Sprague, Annals of the American Pulpit, 1:223-24; Meyer, The Salisbury Family Mansion, 30; and Lincoln, History of Worcester, 160. The ties of respect and friendship between the departed pastor and his supporters were strengthened when Austin's nephew and adopted son, John Hubbard, married Eliza Weir, the niece and adopted daughter of Elizabeth Salisbury. 
28. Austin's preaching was described by his contemporary Leonard Bacon in A Historical Discourse Delivered at Worcester, 45; Goodrich's characterization is from Remarks, 9, 27 (emphasis in original).

29. Remarks, 12.

30. Rebekah Salisbury was married to Stephen Salisbury II, Elizabeth Salisbury's son and the Waldos' cousin. Rebekah Dean Salisbury (Worcester) to Catherine Dean Flint (Boston), May 7, 1839, Waldo Flint Papers, manuscript box F, box 6, folder 8 , AAS. See also the sermon by the Reverend Seth Sweetser, "No. 735, Preached on Sunday after the death of Miss Sarah Waldo," March 23, 1851, Seth Sweetser Papers, octavo vol. 2, manuscript vol. "S," AAS.

31. Origin, 6-7; the Reverend Auretius B. Hull (First Church, Worcester) to the Reverend Joseph Goffe (Milbury Church, Milbury, Massachusetts), February 1824, Old South Church Records, box 2, folder 2, AAS.

32. That this was the intent of the First Church is suggested by the discipline petition from the church members to the Reverend Charles A. Goodrich, March 1818, Old South Church Records, box 1, folder 11, AAS.

33. Letter from the Reverend Charles A. Goodrich to Daniel Waldo, April 1817, cited in Origin, 7.

34. The First Church noted that "it was thought by many that the character and dignity of the Church, and the honour of religion required that something should be done. After the above controversy arose, discipline was inexpedient, and, considering the embarrassed state of the Church, might have been impossible. It was therefore conceded, that, until that question were at rest, nothing could properly be attempted." The controversy referred to were subsequent attempts to return Austin to the Worcester pulpit. Origin, 25-26.

35. The Reverend Samuel Austin (Worcester) to Miss Betsey Flagg (Boylston), August 3, 1814, Samuel Austin Papers, box A, folder 6, AAS. The ecclesiastical council that mediated the dispute granted Flagg a dismission and recommendation upon the condition that she apologize to the brethren, which she did. Thus, while Flagg was in a sense vindicated, it came at the cost of her acknowledgment that she was equally in the wrong. Susan Juster analyzes the gender implications of "crimes of the tongue" among Baptists in Disorderly Women, 88-107.

36. The voting majority was, of course, itself a minority of the church, since it was limited to the male members of the parish and was not composed of the church as a whole. In 1816, women comprised 72 percent of the First Church membership; men comprised 28 percent. "The Old South 
Parish," Proceedings of the Worcester Society of Antiquity, vol. 22 (Worcester, Mass.: Worcester Society of Antiquity, 1907), 174-78.

37. Butler, Walking in the Way, 74.

38. Remarks, 12; Origin, 10; Elizabeth Salisbury to Stephen Salisbury, April 13, 1818, and April 2, 1818, respectively, Salisbury Family Papers, box 18 , folder 2 .

39. Origin, 12-13, quotation from 13 (emphasis in original). To underscore his position, Austin signed his correspondence to the First Church "Your affectionate copastor." Letter from the Reverend Samuel Austin (Burlington, Vermont) to the First Church (Worcester), September 26, 1818, cited in Origin, 18-19.

40. Lincoln, History of Worcester, 161-62; Origin, 20-21.

41. Origin, 24, 25. According to the mutual council, the pro-Goodrich majority represented four-fifths of the congregation.

42. Daniel Waldo was not a party to these proceedings, possibly because he was not a member of the church but only of the parish.

43. Charles A. Goodrich to Elizabeth Salisbury, January 17, 1819, Salisbury Family Papers, box 19, folder 1 .

44. Origin, 41

45. Sarah Waldo and Rebecca Waldo to the First Church, undated but January 1819, in Origin, 31-32.

46. Elizabeth Salisbury to the First Church, undated but January 1819, in Origin, 32-33.

47. Elizabeth Salisbury, Sarah Waldo, and Rebecca Waldo to the First Church, undated but January 1819, in Origin, 39-40.

48. Ibid., 40. The records of the dispute indicate that, while the men of the church participated personally in church meetings and ecclesiastical councils, the women of the church participated only via written petitions. This has had the ironic result of better documenting the women's views than the men's, which, given orally, were not recorded.

49. Ibid., 40-41.

50. See Central Church Records, octavo vol. "W," vol. 5. The quotation is from Butler, Walking in the Way, 10.

51. "Records of the Ecclesiastical Council," August 2, 1820, Central Church Records, octavo vol. "W," vol. 5. The First Church bitterly denounced this ecclesiastical council on the basis that it was an ex parte council. There is 
merit to this argument, for it was not a mutual council but one gathered at the dissenters' request. See letter from the Reverend Auretius B. Hull (Worcester) to the Reverend Joseph Goffe (Milbury), February 1824, Old South Church Records, box 2, folder 2 .

52. Samuel Austin to John Nelson, March 2, 1824, cited in U. Waldo Cutler, The First Hundred Years of the Central Church in Worcester, 1820-1920 (Worcester, Mass.: Central Church, 1920), 18-19. Although well out of the dispute by this point, Samuel Austin followed it with great interest. The Calvinist Church chose the Reverend Loammi Hoadley as its first pastor; it is not clear why Austin was not a candidate, although he resigned the presidency of the University of Vermont in 1821.

53. Men as well as women constituted the dissenters who left the First Church to found the Calvinist Church, but the procedures for leaving an established church for a disputed church differed as a result of the gender inequities of church membership, which was linked to the question of taxpaying. The First Church dismissed without recommending five individualsSarah Waldo, Rebecca Waldo, Elizabeth Salisbury, and Rebekah Richards and her husband, David Richards-but refused to dismiss seventeen others, maintaining that they were still part of the First Church and proposing a mutual council to decide the issue (Origin, 80). Subsequently, the male members of this group, in essence, found a loophole: they separated themselves from the First Church by filing certificates with the town clerk to join the Baptist church in Worcester, as was their right under the Religious Freedom Act of 1811. While the First Church in Worcester initially opposed their actions, ultimately it accepted that the men had left the church (Origin, 53; Remarks, 57). However, certification was required only for church taxpayers; since women were not subject to the church tax unless they were heads of households, married women did not certificate, leaving open the question of their institutional affiliation. The First Church apparently considered the married female dissenters still under its watch and ward and subject to its discipline. When the Calvinist Church was formed in 1820, and Lydia Taylor and Anna McFarland petitioned to be dismissed and recommended to it, the First Church was confronted with a novel problem, namely, did these non-taxpaying married women have the right to leave the First Church for what it considered to be an outlaw church?

54. Anna McFarland and Lydia Taylor to Charles A. Goodrich, October 4, 1820, Central Church Records, octavo vol. “W," vol. 5.

55. See tax lists for 1827, 1832, 1837, 1842, 1845, Central Church Records, folio vol. "W," vol. 4; and List of Persons Assessed in Worcester.

56. Charles A. Goodrich to Anna McFarland and Lydia Taylor, undated but October 1820, Central Church Records, octavo vol. "W," vol. 5. 
57. Anna McFarland and Lydia Taylor to the Calvinist Church, October 14, 1820, Central Church Records, octavo vol. "W," vol. 5.

58. Computed from the list of members, Calvinist Church of Worcester, Manual of the Calvinist Church (Worcester, Mass.: Goddard, 1877). The Worcester data confirm the findings of other historians that a substantial number of antebellum churchgoers did not attend services with their spouses. Paul E. Johnson, Mary P. Ryan, and Harry S. Stout and Catherine A. Brekus reach similar conclusions in their studies of Rochester, Utica, and New Haven churches, respectively. See Paul E. Johnson, A Shopkeeper's Millennium: Society and Revivals in Rochester, New York, 1815- 1837 (New York: Hill and Wang, 1978), 95-115; Ryan, Cradle of the Middle Class, 257; Stout and Brekus, "Declension, Gender, and the 'New Religious History,'" 30.

59. "Copy of the Hon. Daniel Waldo's Deed," July 29, 1826, Central Church Records, folio vol. "W," vols. 1 and 2. Elizabeth Salisbury was not included in the charter, likely because she did not formally join the Calvinist Church until 1830.

60. Central Church Records, March 28, 1823, octavo vol. “W," vol. 5. For the election of John S. C. Abbott, pastor from 1830 to 1835, see octavo vol. 8, undated entry for late 1829; for David Peabody, pastor from 1835 to 1838, see octavo vol. 8, April 22, 1835; for Seth Sweetser, pastor from 1838 to 1878, see folio vol. "W," vol. 10, undated entry for 1838. 